\title{
Analysis of Students' Science Process Skill of Junior High School in Ngawi District in Material Classification and its Changes
}

\author{
${ }^{1 s t}$ Nurul Fathonah \\ Master Program Science \\ Education \\ Universitas Sebelas Maret \\ Surakarta, Indonesia \\ nurul.fathonah24@gmail.com
}

\author{
${ }^{2 n d}$ Sentot Budi Rahardjo \\ Master Program Science \\ Education \\ Universitas Sebelas Maret \\ Surakarta, Indonesia \\ sentotbr@yahoo.com
}

\author{
${ }^{3 r d}$ Baskoro Adi Prayitno \\ Master Program Science \\ Education \\ Universitas Sebelas Maret \\ Surakarta, Indonesia \\ baskoro_ap@fkip.uns.ac.id
}

\begin{abstract}
This study aims to determine the science process skills in material classification and its changes $7^{\text {th }}$ grade of junior high school in Ngawi. The method used in this research is quantitative descriptive. The sample of this research is taken by stratified random sampling technique. The initial profile of science process skills is analyzed from 51 state junior high schools in Ngawi with sampling proportion $10 \%$ in each strata. The sample which were used were 93 students from 3 schools which is include high categorized (SMPN 2 Ngawi), medium categorized (SMPN 2 Karangjati, SMPN 3 Karangjati, SMPN 1 Pangkur) and low categorized (SMPN 3 Ngawi). Technique of data collecting was written test in form of multiple choice. The result of this research from aspect science process skill was: 1) observing was equal to $88,17 \%, 2$ ) classifying was equal to $72,60 \%$, predicting was equal to $23,77 \%$, communicating was equal to $44,97 \%$, measuring was equal to $60,41 \%$, inferring was equal to $28,72 \%$, designing experiment was equal to $46,76 \%$, interpreting data was equal to $42,31 \%$, defining operationally was equal to $27,58 \%$, formulating models was equal to 49,99\%, controlling variables was equal to $25,39 \%$ and formulating hypotheses was equal to 43,91\%. From those data, can be concluded that the science process skills of students in $7^{\text {th }}$ grade junior high school needs to be improved, especially in predicting, communicating, inferring, designing experiment, interpreting data, defining operationally, formulating models, controlling variables and formulating hypotheses.
\end{abstract}

Keywords-science process skills, material classification and its changes

\section{INTRODUCTION}

Natural science learning was intersected directly with the natural surroundings. Students can explore and understand the concept of science systematically through a deeper learning experience, so that science is not only the mastery of a collection of knowledge in the form of facts, concepts or principles but is also a process of discovery.

In this $21^{\text {st }}$ century, the graduates are expected to have double skills of current competence. The four important skills trained by the teacher to the students are 4C (Critical thinking and problem-solving, Communication, Collaboration, Creativity and innovation) [1]. In science subject, the four skills are integrated to the science process skills. The science process skills can equip students' thinking skills [2].

When viewed from the skills that are included into science process skills, it is clear that the science process skills are important in science learning as the basis for improving the other thinking skills which are much more complex such as $4 \mathrm{C}$ that has been explained before. It is also supported by Aydinli [3] which states that teachers should pay great attention to students' science process skills by providing handson activities' task oriented to improve their understanding of a science concept.

Harlen [4] explains that science process skills have a very important role in the development of knowledge. Carrin and Sund [5] also explained that there is a relationship between process, attitude, and product. The process can be defined as a complex skill device used by the scientists in conducting scientific investigations. The process or scientific method is a great concept that can be broken down into a number of components that must be mastered if the person is going to do research and development in the field. Scientist develop theories through science process skill.

Based on observations and interviews in schools, process learning has followed the 2013 curriculum. That has integrated a scientific approach. However, process learning in classroom rarely to practice. That is caused students' science process skill less than optimal. Besides, in classification of matter and changes has low students' absorption. That's can shows in national exam score application called PAMER UN. The data students' absoption are SMPN 2 Ngawi 70,88, SMPN 2 Karangjati 45,91, SMPN 3 Karangjati 45,98, SMPN 1 Pangkur 47,54 dan SMPN 3 Ngawi 36,90. Understanding concept SMPN 2 
Karangjati, SMPN 3 Karangjati, SMPN 1 Pangkur and SMPN 3 Ngawi in this subject matter is lower than average province 52,66 and national 53,60 and SMPN 2 Ngawi is highest from others.

Science process skills make science learning easier, increase the students' activities, and increase the students' responsibility toward learning they conduct. Those skills teach the students scientific methods or researches [6,7]. They are interdisciplinary and suitable for every field of science. The importance of the skills for the students include how to learn to implement sciences in real learning and in everyday life, how to apply concepts, how to generate theories and rules in learning $[6,8]$.

The knowledge that the world society has accumulated is improving and increasing so fast as a result of testing of new ideas around the world [10] so that it is necessary to teach people how they can reach the knowledge instead of teaching all knowledge in educational system. In this respect, the place of scientific process skills is very important in teaching ways of reaching knowledge and has become an important aim in science education.

The science process skills can be classified into 2 types, namely: basic and integrated ones [11]. The basic science process skills include observation, measuring, inferring, classifying, predicting, and communicating. Integrated science process skills include interpreting data, controlling variables, defining operationally, formulating a hypothesis, designing experiment and formulating models.

Furthermore, according to German [17] there are two skills that are used in the world of science. Firstly, basic science process skills that related to the ability to conduct empirical - inductive reasoning as well as providing basic skills in conducting scientific investigations. Secondly, integrated science process skills that associated with ability to perform the hypothetic-deductive reasoning. These skills are used to solve problems or conducting experiments. Science process skills cannot be separated in practice understanding of the concepts involved in a study and application of science.

Karamustafaoglu [6] explains that the science process skills facilitated the science learning and students' activities, increased the students' responsibility for their learning, and teach the students about scientific methods or research. Besides, these skills are also useful to think about how to get information, to think about problems and to formulate conclusions. These skills are suitable for all fields of science. The important thing for the students is how to learn to implement sciences in real learning and in everyday life, to apply concepts and to generate theories and rules in learning. The students need them more to familiarize themselves in the science process skills.
This study aims to determine the profile science process skills in classification of matter and changes $7^{\text {th }}$ grade of junior high school in Ngawi.

\section{RESEARCH METHODS}

This research was a descriptive quantitative research that described the profile of student science process skill of classification of matter and its changes. The sample of this research is taken by stratified random sampling technique, because the sample comes from several strata. Determination of high, medium and low strata based on the national exam score in 2017. The score national exam can be seen in application called PAMER UN developed by education ministry of Indonesia. Schools with score national exam above of average score national axam of ngawi districts $+1 / 2$ standard deviation are included in high category, and schools having score national exam under of average score national axam of ngawi districts - 1/2 standard deviation are included in low category, the rest included in medium category schools.

The initial profile of science process skills is analyzed from 51 state junior high schools in Ngawi with sampling proportion $10 \%$ in each strata. Subjects of the research were 93 students of $7^{\text {th }}$ grade from high, medium and low categorized school in Ngawi at the academic year 2017/2018. State junior high schools in Ngawi was included high categorized are 8 schools, medium are 30 schools and low are 13 schools. From the high categorized was taken one school, medium categorized was taken 3 schools, and low categorized was taken one. This selection schools of this study are high categorized (SMPN 2 Ngawi), medium categorized (SMPN 2 Karangjati, SMPN 3 Karangjati, SMPN 1 Pangkur) and low categorized (SMPN 3 Ngawi).

Data of the research was obtained from the result student's test using multiple choice test. This instrument consist of 12 question that were based on the learning indicator on a syllabus. The instrument used in internal validation by 2 lecturers refers to the aspect of the science process skills used. For the evaluation of science process skill test, correct and wrong answers have been scored as 1 and 0 respectively. The quality of the test result was determined by the average percentage score obtained by each science process skills' indicators. The interpretation of junior high school science process skills quality was shown in Table I.

TABLE I. CRITERIA OF SCIENCE PROCESS SKILL'S ANALYSIS RESULT INTERPRETATION

\begin{tabular}{|c|c|}
\hline Score Range & Category \\
\hline $0 \%-20 \%$ & Poor \\
\hline $21 \%-40 \%$ & Fair \\
\hline $41 \%-60 \%$ & Moderate \\
\hline
\end{tabular}




\begin{tabular}{|c|c|}
\hline Score Range & Category \\
\hline $61 \%-80 \%$ & Good \\
\hline $81 \%-100 \%$ & Very good \\
\hline
\end{tabular}

The analysis score of science process skills at junior high school student $\geq 61 \%$ indicate good result [18].

\section{RESULT AND DISCUSSION}

The score of science process skills at junior high school students are presented in Figure 1 below.

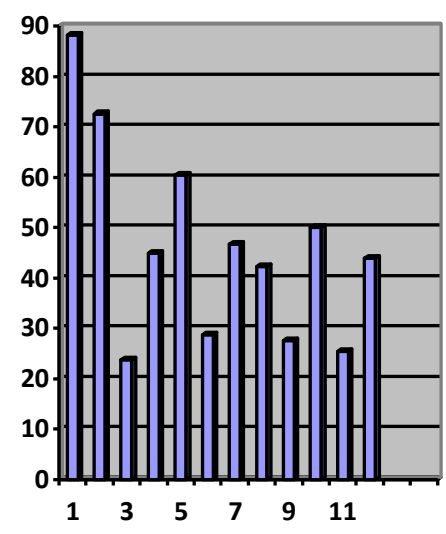

Indicator of science process skills
Note:
1.Observing
2.Classifying
3.Predicting
4.Communicating
5.Measuring
6.Inferring

\author{
7.Designing experiment \\ 8.Interpreting data \\ 9.Defining operational \\ 10.Formulating model \\ 11.Controlling variable \\ 12.Formulating hypothesis
}

Base on Figure 1 above can be described that the highest percentage of science process skills by students is the observing aspect that is with value 88.17 . The followed by the classifying aspect that is with value 72.60 . The percentage aspect of predicting is 23.77 , that islowest value of aspect science process skills.

Criteria of science process skill's analysis result interpretation are very good level is observing with score $>81 \%$, good level are classifying and measuring with score between $61 \%-80 \%$. Moderate level are communicating, designing experiment, interpreting data, formulating hypothesis, and formulating models with score between 41\%-60\%. Fair level are predicting, inferring, defining operationally, and controlling variabel with score between $21 \%-40 \%$. From the data, shows that science process skill include fair level and moderat level still can be improved with learning process in the classroom.

The average score of science process skills at junior high school students are presented in Tabel 2 below.
TABLE II. THE AVERAGE SCORE OF SCIENCE PROCESS SKILLS

\begin{tabular}{|l|c|l|c|}
\hline $\begin{array}{l}\text { Basice Science } \\
\text { Process Skills }\end{array}$ & $\begin{array}{c}\text { Percentage } \\
(\%)\end{array}$ & $\begin{array}{c}\text { Integrated } \\
\text { Science } \\
\text { Process Skills }\end{array}$ & $\begin{array}{c}\text { Percentage } \\
(\%)\end{array}$ \\
\hline Observing & 88.17 & $\begin{array}{l}\text { Designing } \\
\text { experiment }\end{array}$ & 46.76 \\
\hline Classifying & 72.60 & $\begin{array}{l}\text { Interpreting } \\
\text { data }\end{array}$ & 42.31 \\
\hline Predicting & 23.77 & $\begin{array}{l}\text { Defining } \\
\text { operational }\end{array}$ & 27.58 \\
\hline Communicating & 44.97 & $\begin{array}{l}\text { Formulating } \\
\text { model }\end{array}$ & 49.99 \\
\hline Measuring & 60.41 & $\begin{array}{l}\text { Controlling } \\
\text { variable }\end{array}$ & 25.39 \\
\hline Inferring & 28.72 & $\begin{array}{l}\text { Formulating } \\
\text { hypothesis }\end{array}$ & 43.91 \\
\hline Average & 53.11 & & 39.32 \\
\hline
\end{tabular}

The aspect of the basic science process skill is the highest is observing and the lowest one is predicting. In the integrated science process skill, the highest is formulating models, and the lowest is defining operationally. The basic process skills provide a foundation for learning the integrated skills [11]. Stated that high percentage rate of basic science process skills $(62.80 \%)$ as compared to the integrated science process skills $(37.20 \%)$. The results also indicated that the number of basic process skills is significantly higher than the integrated process skills in the West African senior secondary school certificate physics practical examinations in Nigeria [12].

The development of student science process skills is very important in education, because it can facilitate students' learning ability and support critical thinking skills. One of the most useful steps to promote science process skill is to train student to develop the skills of the science process [13]. Science process skills can be trained and taught to the student through various approaches, methods, media, and evaluation instruments. For example, the teachers should train the students to always think scientifically and give them exercises on the SPS to practice their science process skills. Based on the research conducted by Lati, Supasorn, and Promarak [14], inquiry approach was proven to be an effective learning approach to improve the conceptual understanding, critical thinking skills, and science process skills in Thailand. Inquiry is the most effective approach to improve the students' science process skills. This step is suggested so that teachers can expect a lot of improvement in the students' ability after practicing several experiments. Moreover students need several opportunities to improve their skills in various contexts.

Gezer [15] conducted a case study on the preservice science teachers' laboratory usage selfefficacy and scientific process skills that led to the conclusion that inquiry and research based learning environments could improve science process skills more than the laboratory traditional courses. 
Ambross, Meiring, and Blignaut [16], research on the implementation and development of science process skills in the natural sciences. The results of this research recommend that the government or any educational institution needed to support teachers, for instance, by holding workshops to improve the teachers' understanding on science process skills.

\section{CONCLUSION}

Based on the result of the research can be concluded that the science process skill measured in this research there are 12 aspect of science process skills. The six aspect of basic science process skills are: observing, classifiying, predicting, measuring, inferring and communicating, and six aspect of integrated science process skills are: identifying variables, controlling variable, interpreting data,formulating hypothesis and formulating models. The percentage of basic science process skill is higher than integrated science process skill. The science process skills of students in $7^{\text {th }}$ grade junior high school needs to be improved, especially in predicting, communicating, inferring, designing experiment, interpreting data, defining operationally, formulating models, controlling variables and formulating hypotheses.

\section{REFERENCES}

[1] P. Griffin, "Assessment and Teaching of $21^{\text {st }}$ Century Skills: Methods and Aprroach," Springer. London, 2015.

[2] B. S. Bloom, "Taxonomy of Educational Objective: The Classification of Educational Goals Handbook I Cognitive Domain," (Green and Co, Longmans, New York, 1956).

[3] E. D. Aydinli, Z. K. Unlua, N, Ozturk, Demir and E. Benli, “Turkish Elementary School Students' Performance on Integrated Science Process Skill", Procedia Social \& Behavioral Sciences, vol. 15, 2011, pp. 3469-3475.

[4] W. Harlen, "Purposes and Procedures for Assessing Science Process Skills," Assessment in Education, vol 6, 1999, pp. 129-144.

[5] A. A. Carrin, and R. B. Sund, "Teaching Modern Science," Charles E Merril Publishing Company, 1985.
[6] S. Karamustafaoglu, "Improving the Science Process Skills Ability of Science Student Teachers Using I Diagram", Eurasian Journal of Physics \& Chemistry Education, vol. 3, 2011, pp. 26-38

[7] W. M. Roth, and A. Roychoudhury, "The Development of Science Process Skills in Authentic Contexts," Journal of Research in Science Teaching, vol. 30, 1993, pp.127-152.

[8] M. Hodosyova, J. Utla., M. Vanyova., and V. Lapitkova, "The Development of Science Process Skills in Physics Education," Procedia Sosial and Behavioral Sciences, vol. 186, 2015, pp. 982-989.

[9] F. Karsli, F. Yaman, and A. Ayas, "Prospective Chemistry Teachers' Competency of Evaluation of Chemical Experiments in Terms of Science Process Skills". Procedia Social and Behavioral Sciences, vol. 2 , 2009, pp. 778-781.

[10] M. J. Padilla, "The science process skills. research mattersto the science teacher," No. 9004. Reston, VA: National Association for Research in Science Teaching, NARST, March 2018, 1990.

[11] R. W. Dahar, “Teori-Teori Belajar,” Erlangga, 1996.

[12] A. O. Akinbobola, and F. Afolabi,"Analysis of science process skills in West African seniorsecondary school certificate physics practical examinations in Nigeria," American Eurasian Journal of Scientific Research, vol. 5, 2010, pp. 234-240.

[13] S. Erkol and I. Ugulu, "An investigation On Environmental Attitudes of Gifted Students and The Assessments In Terms of Some Demographic Variables," International Journal Environment Science Education, 2013, vol.11, pp. 779.

[14] W. Lati, S. Supasorn., and V. Promarak, "Enhancement of Learning Achievement and Integrated Science Process Skills Using Science Inquiry Learning Activities of Chemical Reaction Rates". Procedia Social and Behavioral Sciences, vol. 46, 2012, pp. 4471-4475.

[15] S.U. Gezer, "A Case Study on Preservice Teacher Laboratory Usage Self Efficacy and Scientific Process Skills," Procedia Social Behavioral Science, vol. 174, 2015, pp. 1158-1165.

[16] J. Ambross, L. Meiring., and Blignaut, "The Implementation and Development of Science Process Skills in the Natural Sciences: A Case Study of Teachers' Perceptions," Africa Educational Review, vol.11, 2014, pp. 459-474.

[17] P. J. Germann, "Testing a Model of Science Skills Acquisition: An Interaction with Parents' Education, Preferred Language, Gender, Science Attitude, Cognitive Development, Academic Ability, and Biology Knowledge," Journal of Research in Science Teaching, 1994.

[18] Riduwan., "Skala Pengukuran Variabel-Variabel Penelitian," Alfabeta, Bandung, 2010. 